\title{
A New Significance of Blood as a Symbol for Both Contagion and Salvation in the Underworld Films
}

\author{
By Antonio Sanna
}

Fall 2013 Issue of KINEMA

\section{A NEW SIGNIFICANCE OF BLOOD AS A SYMBOL FOR BOTH CONTAGION AND SALVATION IN THE UNDERWORLD FILMS}

\begin{abstract}
In this paper I shall examine the critical debates on the symbolism of blood in Gothic literary stories and horror films in order to apply them to the cinematographic tetralogy of Underworld. I shall specifically argue that, similarly to their predecessors, this recent tetralogy presents blood as the vehicle for the contagion of a victim with an incurable condition and, thus, as an allegory for contemporary terminal illnesses such as AIDS. Nevertheless, blood could be simultaneously interpreted also as a means for physical recovery from injuries and as a transmitter of information on personal and communal history, of individual memories and hereditary concerns for the well-being of a community.
\end{abstract}

According to several of its literary and cinematographic representations, a vampire mainly reproduces through the exchange of blood: it transforms another individual into a vampire by merely mixing his own blood with that of its victim through the bite. Blood thus works as a reproductive liquid as much as semen, although such an exchange of fluids takes place by means of the mouth of the vampire. According to Cindy Hendershot, vampires thus possess "only one sex organ - the mouth" and are also "biologically undifferentiated" because of the cancellation of genital sexuality (22-23). The very fact that the contagion of blood from a vampire implies the transformation of a human being into a murderous monster, who needs to be finally killed by the good characters of the narrative in order for the social and natural status quo to be reasserted, has provoked a series of debates among the critics who associate vampiric contagions with the transmission of venereal diseases and the concern for purity (Spencer 310, Hopkins 110). For instance, the eponymous villain of Bram Stoker's 1897 novel Dracula has been "associated with degeneracy" (Smith 94, 141) and the spread of syphilis at the end of the nineteenth century, an infection which, at the time, was seen as both a medical problem and a metaphor for social and cultural degeneration. The link between gore and sex was then only suggested in productions such as F.W. Murnau's Nosferatu (1922) and Ted Browning's Dracula (1931), but it was particularly emphasized in the films on vampires by the Hammer studio, especially through the representation of the female characters contaminated by Dracula as becoming provocative and libidinous temptresses and sensual femme fatales. Consider, for example, the character of Helen (Barbara Shelley) in Terence Fisher's Dracula: Prince of Darkness (1965). Initially, she is a fearful but also severe woman in both her behaviour and choice of costumes. After the Count's bite, she is transformed into a sensual and voluptuous vampire (precisely like Lucy in Stoker's work), who is eager to bite and thus contaminate the surrounding humans.

On the other hand, many examples could be offered of the death of a vampire's victim (which subsequently leads to the transformation into a monstrous being) as metaphorically implying the contagion of human blood with a lethal illness. This is the case of John Badham's film Dracula (1979), for instance, where, after the nightly visitation of the Count (interpreted by Frank Langella), a scene rather crude portrays Mina (Jan Francis) waking up in the morning without being able to breathe and dying of asphyxia within seconds. Mina is presented from the beginning of the film as a very debilitated and pale woman with poor health and a weak body. The contact with the vampire advances her illness to its final stage. (See Figure 1; copyright Universal Pictures.)

The association of vampirism with a contagious virus or illness is reprised in Francis Ford Coppola's Bram Stoker's Dracula (1992), which introduces Van Helsing (Anthony Hopkins), the major opponent of the vampire, while giving a lecture in which he puns on the parallel progression of civilization and syphilization, as Lisa Hopkins has pointed out (110). The frequent images of blood in Coppola's film have also been 
interpreted as referring to the discourses on - and fear of - AIDS that were made in the early 1990s when such an epidemic's diffusion became an internationally recognised concern (Botting 177). This has been noted by Catherine Spooner as well, who argues that "AIDS [. . . ] has unsurprisingly been absorbed into contemporary Gothic modes of representation" (74).

Such a symbolic function of blood is possible, as the critics have repeatedly asserted, because, by representing fictional characters and creatures that could never exist in the "real" world, horror films are very often intended as vehicles of other messages, messages which sometimes could not be openly stated in contemporary society. According to Cynthia A. Freeland, horror films address "human fears and limitations" (273), whereas Paul Wells affirms that monsters could be conceived of "as metaphors; as projections of particular threats, fears and contradictions that refuse coexistence with the prevailing paradigms and consensual orthodoxies of everyday life" (9). In the case of contemporary vampires and werewolves, the spread of the virus could therefore be seen as a metaphor for sexually-transmitted diseases such as syphilis or AIDS still plaguing contemporary society.

The sensual approach of the vampire to its victim (usually occurring in a bedroom) is instead represented as a brutal aggression and physical struggle in the case of the werewolf. The contagion of a human being from such a monster is usually caused by the creature's bite or even by a single scratch from its claws. The werewolf itself is mainly characterized as a creature which completely loses both the physical traits and the intellectual faculties of human beings and acts only according to its murderous instincts. For this reason, it has been repeatedly seen as "a figure who frightens us especially because he is at once a man, but also something else; a defector from the social contract, one who can transform himself into something that is primeval and outside convention in both form and morality" (Naficy 211). Fear of the beast growing inside one's self and taking the (corporeal and moral) place of the human individual is also linked with the horror of dying because of the infection, with the excruciating pains of the transformation and with the terror of causing other people's death. Contrary to the majority of vampires, werewolves are indeed tormented by their own monstrosity.

Popular films such as George Waggner's The Wolf Man (1941), John Landis's An American Werewolf in London (1981) and the recent remake The Wolfman by Joe Johnston (2010), all exhibit the terror of an individual who is vexed with an incurable condition which deeply affects his body and mind as well as (after the transformation) causing the death of the surrounding people and possibly of the character's family members and dear ones. The protagonists of these films do not initially accept or believe in the contagion they have suffered because of the encounter with the monstrous creature. For example, the character of David Kessler (David Naughton) in Landis's film refuses to believe in the apparition of his dead friend Jack Goodman (Griffin Dunne), whose progressively-decomposing ghost explains: "the wolf's bloodline must be severed. [. . . ] You'll kill people" and thus establishes an explicit connection between blood and murderous instincts. David does not listen to his friend's advice to commit suicide in order to avoid a massacre of innocent persons. It is only after the first murders that he realizes the dangers of his condition for the surrounding people, but does not have enough strength and courage and only manages to hide inside a porno theatre.

Similarly, in the 2010 film by Johnston, Sir John Talbot (Anthony Hopkins) confines himself inside a cell during the full moon nights to prevent any nocturnal murderous raids and, therefore, to avoid the further contagion and death of other individuals. The story's protagonist Lawrence Talbot should be confined as well once he has been bitten, but he is instead set free by Sir John to be subsequently blamed as a murderous psychopath. This is interestingly contrasted with Lawrence's sense of entrapment into his own mind's demons, such as his adversity towards his father, his resentful guilt for abandoning his brother and his evident trauma for his mother's violent death.

The transmission of a fatal disease through the passage of blood or through bite is depicted also in the recent cinematographic tetralogy on vampires and werewolves Underworld (2003-12). In these films, blood is a vehicle for the transmission of a fatal illness. This is specifically true if we consider that the diffusion of Lycan blood is repeatedly portrayed as a form of infectious contagion. At the beginning of Len Wiseman's Underworld Evolution (2006), indeed, the vampires immediately burn the bodies of the people who have been bitten by William Corvinus, the first werewolf, in order to avoid their transformation and therefore to stop 
the spread of what Viktor, the most ruthless of the three leaders of the vampires (admirably interpreted by Bill Nighy), calls "William's pestilence". The idea of finding a cure for the infected people is not contemplated at all by the vampires. The infection must be defeated with the annihilation of the bodies by means of fire and is thus immediately associated with the necessary execution of the individual.

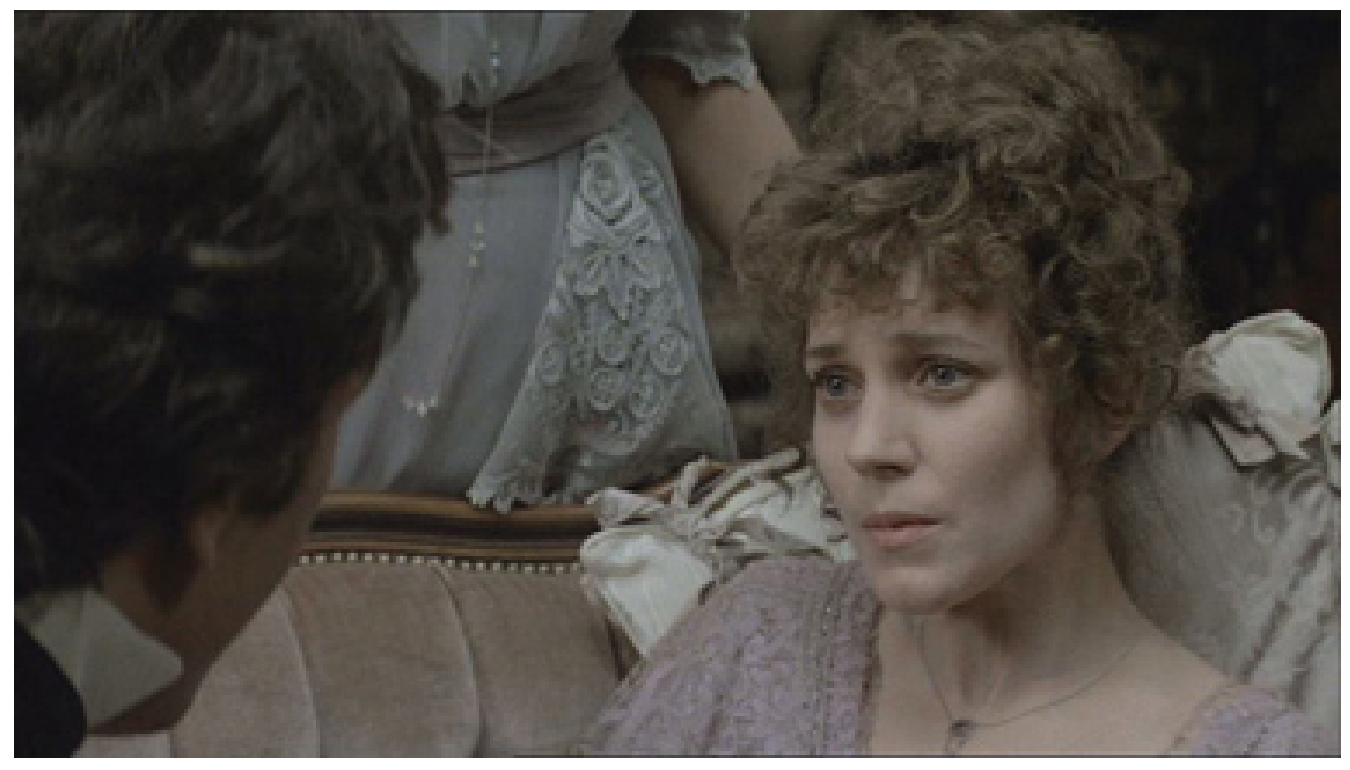

Figure 1: A pale and weak Mina (Jan Francis) repeatedly faints in Badham's Dracula

In the same respect, the narrating voice of Patrick Tatopoulos' 2009 prequel Underworld Rise of the Lycans defines werewolves as "a vicious and infectious breed, unable to take human form ever again". On the one hand, the infection is thus associated with the loss of human identity, as if to suggest that an infected individual should not be even considered as human anymore. In Tatopoulos' film, even the human beings describe it as a contagious plague which exterminates the servants of the noble men. Janosh (Tim Rabi), the spokesman for the nobles who regularly pay a tribute of silver to the vampires in exchange for protection against the Lycans, reports that "our workers [have been] infected, turned to beast", thus further contributing to the association of contaminated people with the loss of human identity and rights. Similarly, the character of Raze (Kevin Grevioux), later to become second in command of the Lycans, defines it as "a curse" - a term frequently used in films on werewolves, such as in Mike Nichols' Wolf (1994) and Grant Harvey's Ginger Snaps Back: The Beginning (2004). On the other hand, the transformation of a human being into a vampire is depicted as a privilege granting immortality as much as an aristocratic social status to the individual. This occurs near the end of Len Wiseman's Underworld (2003), when Viktor admits having massacred the family of his protegee Selene (Kate Beckinsale), but adds that, by being bitten, she has instead received the gift and privilege of immortality.

The contagion from a Lycan is therefore frequently associated with the social ostracism and prejudice of the people who fear the diffusion of epidemics. This is certainly exemplified by the behaviour of the elder vampire Viktor, who is the major exponent of a discourse favouring the purity of blood and continually discrediting the Lycan species. In the initial scene of Underworld Evolution (set, according to the caption, in $1202 \mathrm{AD}),{ }^{(1)}$ Viktor tells the second vampire elder Markus (Tony Curran) that if he only speaks his brother William's name, he would choose termination for him. According to Viktor, werewolves should not be even mentioned and are to be exterminated, to be annihilated like a pestilence. Viktor also abhors the thought of anyone who is not a pure blood and propagandises a discourse against class mobility.

In Rise of the Lycans, he in fact condemns his beloved daughter Sonia (Rhona Mitra) to death for being pregnant with a Lycan's child, whom he describes as "a monstrosity". Similarly, in Underworld, when informed of the Lycans' plan to create a genetic hybrid of the two species, Viktor affirms: "there can be no such thing, and to speak of it is heresy". A close-up focuses on the vampire leader's astonishment while 
he almost whispers the words, as if fearing to be heard whilst talking about that subject. Viktor seems to be even trembling when he learns of the hybrid, his eyes fixed on the Lycan scientist who is spelling the "heretical" words. He thus underlines the fact that the intermingling of the two species and, specifically, of the different blood lines is an abominable subject that must not be even mentioned. He uses the term "heresy" to align his argument with an almost religious discourse touching on the most profound and ancient traditions and established rules dating back centuries in vampire history.

Subsequently, after hearing the captive Lycan scientist's explanation that Michael Corvin (last human descendant of Alexander Corvinus, the first immortal, interpreted by Scott Speedman) could become stronger than any representative of both species if his blood, already infected by Lucian - leader of the werewolf clan (Michael Sheen) - would be mixed with that of an elder vampire such as Viktor himself, the vampire elder merely utters: "Abomination", with a disgusted face and almost breathless at the mere thought of such a fact. Viktor's affirmations and actions therefore perfectly represent the kind of discrimination against the members of a minority (such as homosexual men or HIV-positive persons) that still exists in contemporary society and is often dictated by the (more or less conscious) fear of being contaminated. We could thus easily apply Siamak Tundra Naficy's argument that "through the process of stigmatization and exclusion, specific individuals can be completely ostracised from particular social interactions simply because they happen to have a certain characteristic or be a member of a marked group or category" (212) to the exclusion and stigmatization of the Lycans promoted by Viktor and enacted by many vampires.

Contrary to the decision willingly taken by the protagonist of An American Werewolf in London and by Sir John in The Wolfman to isolate themselves from the human community in order to protect its members, in the Underworld films the association of werewolf's blood with an infectious disease primarily constitutes an argument maintained by the rival species of the vampires. This issue is expanded in Mårlind \& Stein's Underworld Awakening (2012), whose story begins with the human discovery of the two supernatural species and the immediate mass cleansing of them. The Antigen scientist Dr. Jacob Lane (Stephen Rea), appearing in the initial sequence which represents the TV reports on the cleansing, specifies: "there is no cure" and suggests to find vampires and werewolves by subjecting all citizens to a test which shall "verify if you're clear of infection". Selene herself has become a laboratory test subject for the Antigen scientists, who use her DNA to find a cure for the infection.

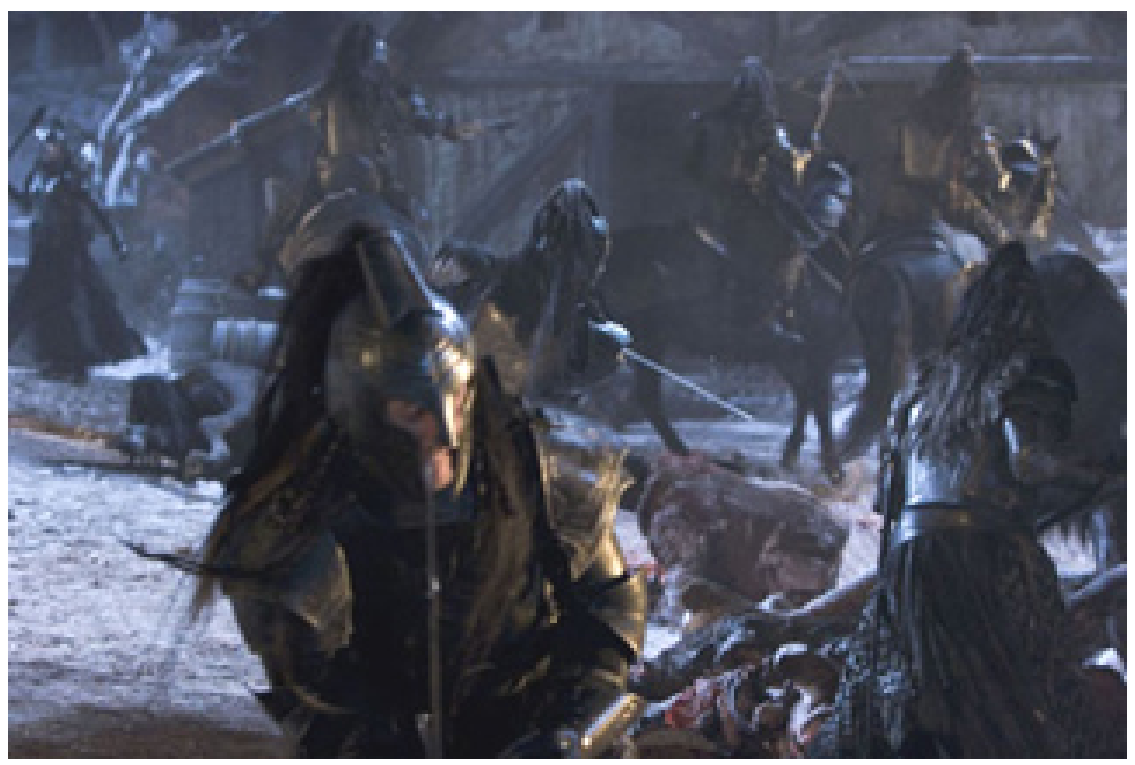

Figure 2: Vampires eradicate the contagion by killing the Lycans and burning their bodies at the beginning of Underworld Evolution (copyright Screen Gems)

In these films, blood is particularly linked to those moments in which violence is openly displayed, especially during the slaughters between the two eternally-rival clans. Blood is visible on the corpses of the members 
of the two species after the violent fights against each other (whether enacted by sword or by rifles) and it is thus mainly associated with those moments in which death is represented. This would confirm the argument that it is associated with the contagion of mortal diseases. We could refer, for example, to the fact that, by making sure Michael becomes a werewolf and thereby forced to join the clan, Lucian condemns the human to death. After the contagion, Lucian establishes and explicitly affirms Michael's membership to the species and clan of the Lycans by affirming: "there's no going back, there's no going anywhere, the vampires will kill you on sight, just for being what you are: one of us. You are one of us". Could we not compare Lucian's remarks that "there's no going back" to the thoughts of a person who has been diagnosed with a mortal disease? This seems to be confirmed by the fact that, throughout the entire narrative developed in the films, the immortal war between the two species is always referred to with the terms "blood feud", as if to underline the difference in blood as the main reason for the continuous struggle. Certainly, this is partly allusive to a discourse about nobility and membership to a social class, but we could also interpret the difference in blood in terms of "healthy" versus "infected" blood.

Belief in class differences is a fundamental thematic concern of the tetralogy. Indeed, following the tradition established by Stoker's representation of the villain as a Count, vampires are here represented as aristocratic beings, accustomed to all privileges and leisure of contemporary society (such as expensive cars, computers, mobile phones and security cameras) as well as to vices such as smoking or luxuries such as elegant dresses. They are portrayed as nobles accepting only the company of each other and intent on enjoying a life of pleasures. This is particularly emphasised near the beginning of Underworld, in the scene that depicts the vampires' reunion in the luxurious hall of their mansion. In this sequence, the vampires celebrate the forthcoming arrival of their elder leader Amelia (Zita Görög) by drinking blood from glasses, smoking cigarettes and apparently flirting with each other in what looks almost as a sort of elegant brothel. Later, in the second scene reuniting them in the red-decorated hall, one of the members of the clan makes a public toast and specifically says: "our noble house may be separated by a great ocean, but we are equally committed to the survival of the blood line". Thus, the importance of being noble, of belonging to an aristocratic order, is linked with blood and the survival of the species.

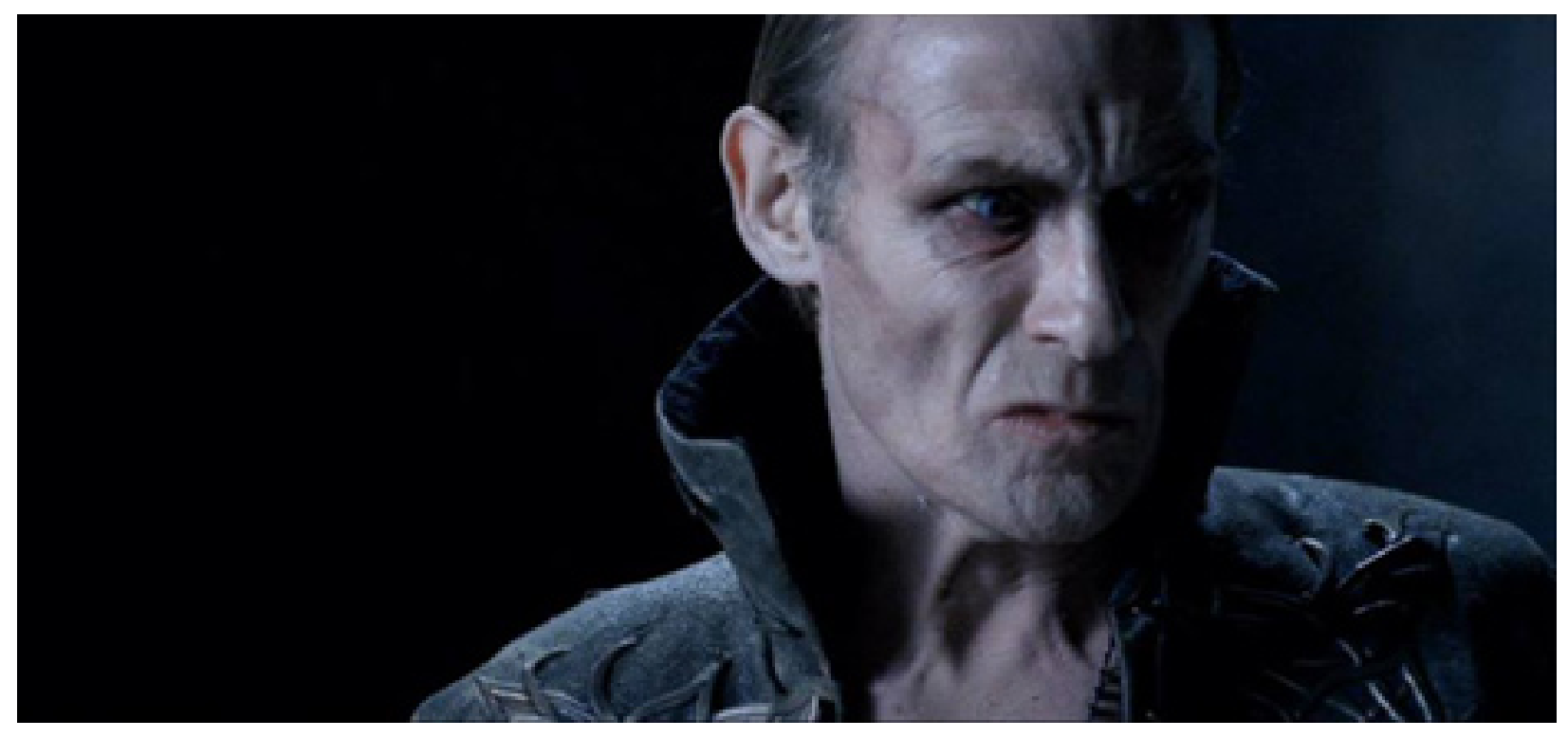

Figure 3: Viktor (Bill Nighy) disgustedly pronounces the word "abomination" when listening to the Lycan scientist in Wiseman's Underworld (copyright Screen Gems)

On the other hand, we could argue that the werewolf characters of the Underworld films represent instead a more sensual, impulsive and almost animal need for blood. Lycans live in the underground, in a dark and dilapidated underworld (which could suggest that the titles of the films are specifically referred to the werewolves and are intended for the viewer to sympathize a priori with them) and lack the privileges that vampires have. These films thus consistently explore a series of conflicts that begin with spatial contrast 
(Sanna 134). This is in the case Underworld Rise of the Lycans, which juxtaposes the Gothic interior settings constituting the vampires' castle to the exterior spectacle of wilderness represented by the werewolves living in the uninhabited woods where the ferocious aggressions of the human victims occur. These spatial contrasts constitute the groundwork for the thematic contrasts: violence inside of the walls is made of the abject slavery inflicted by the vampires on the Lycans, whereas outside of the walls the werewolves inflict violence instinctively only as a means to obtain nourishment or reproduction. Setting the underground corridors against the mansion in Underworld, the film's central contrast between the purity of blood and the (alleged) infection diffused by werewolves is thus represented by the contrast between the closed space of political intrigues and aristocracy and the open space of wilderness and rebellion.

Although Lycans are depicted as huge anthropomorphic creatures that are said to be dedicated to the hunt of food, viewers are actually never shown the werewolves whilst assaulting human beings. Indeed, with the exception of the violent fights between the supernatural species and the human security forces intent on exterminating them in Awakening, the representation of the lethal action of both vampires and werewolves against a human victim is actually very rare in the entire tetralogy: these films introduce a supernatural world that exists at the borders of the human community and does not interfere with it. The representation of blood as necessary to the satisfaction of these creatures' thirst or hunger is limited to the drinking of blood by the vampires from adorned cups and precious glasses. For this reason, we could consider the vampires shown in these films as representing an almost cerebral and purified approach to blood. Contrary to the majority of their literary and cinematographic predecessors, they never bite human beings or crave for their blood: they even organize their rations by means of drip sacs containing synthetic blood, thus not depending on the human community any longer.

This could be easily demonstrated by comparing the behaviours of Count Dracula in Freddie Francis's Dracula Has Risen from the Grave (1968) or in Alan Gibson's Dracula AD. 1972 (1972) with that of Selene in Underworld. In the two Hammer productions, Dracula (interpreted by Christopher Lee) chooses a specific female victim, repeatedly visits her during the night penetrating into her bedroom, and then merely disposes of her services once he is satisfied in his hunger or appetite. Selene is instead protective towards the human Michael, she is even attracted by him and, most importantly, she is never shown while drinking blood, as if she did not need the sustenance deriving from it.

Nevertheless, blood is not only characterized as a vehicle for the contagion of infectious diseases in these films, but it is also given a positive characterization. This could be firstly confirmed by the fact that the scenes which actually display sexual contact among the main characters never portray any kind of contagion or any game of submission or of power. In Underworld Evolution, sex between Selene and Michael is shown as clean and sweet, as the completion of two individuals and the union of the couple. This is also the case of Sonia and Lucian, whose sexual encounter in Underworld Rise of the Lycans portrays no acts of violence or prevarication of one sex over the other. There is no passage of blood between the two participants in these sequences. Contrary to the fact that in "real" life, the contagion of venereal and mortal diseases can occur through the practice of unprotected sex, in these films sex is a liberating act, which is located far from the eyes of a disapproving and prejudiced community governed by (and imposing) strict rules of (sexual) behaviour.

The dangers of unprotected sex alluded to in films such as Ginger Snaps (2000) - where the protagonist passes the werewolf virus to her sexual partner (Spooner 106) - are therefore exorcised in the Underworld films. Moreover, sex among the members of the two monstrous species is pictured as natural and romantic, contrary to the violence inflicted by a vampire or werewolf on a human victim as represented in previous films, from Fred F. Sears' The Werewolf (1956) to Neil Jordan's Interview with the Vampire (1994). In the former, for example, the character of Duncan Marsh (Steven Ritch) attempts to strangle and rip the throat of all the persons in his path, behaving like an animal chased by human hunters. In Jordan's film, Lestat (Tom Cruise) is highly irreverent towards some of his victims, initially seducing them and then even mocking their last attempts at survival.

Blood is given a positive connotation by being represented also as the vehicle for the salvation of the species in Underworld. The first instalment of the tetralogy presents many close-ups of the blood inside the phial in which the experiment for the creation of a werewolf-vampire hybrid is conducted. Lucian's experiment 
is seen as a sort of cure against the aggression of the vampires: according to him, it shall bring "an end to this conflict", conflict which the vampires initiated when Viktor decided to persecute the Lycans who did not accept to live in abject servitude. The creation of a hybrid with powers superior to those of both species signifies the possibility to strongly oppose and rebel against the vampires' extermination of the Lycans. This is precisely what occurs at the end of Underworld Evolution, with the death of the three elder vampire leaders (those who were the most committed to the fight against the Lycans) producing a chaotic situation during which the Lycans gain sufficient time to regroup, replenish their pack and prevaricate over the remaining leaderless vampires.

Another positive characterization of blood is due to its depiction as the biological repository of memories. By biting an individual, both vampires and Lycans are able to access his/her memories, record them and also share their own. It is in the blood that acts of memory, knowledge and recognition take place. This occurs when Markus, the vampire elder waking up in the second instalment of the series after two centuries of sleep, bites Kraven (Shane Brolly) to discover the truth about the latter's betrayal of the clan. By saying "Why would I listen to your lies, when the journey to the truth is so much sweeter?", Markus associates truth with the experience of drinking blood, or, we could say, with the very flavour of blood.

In this scene, the focus on the great flux of blood pouring from Kraven's throat is alternated with the vampire's memories following each other in a series of quick cuts reconstructing chronologically the main events of the vampire's life. Blood thus becomes synonymous with intimacy and truth in the tetralogy, a vehicle for the transmission of hereditary geniuses as much as of family history and history of the clan. This is exemplified by the fact that in Underworld Michael dreams about the Lycan clan's past and sees in his unconscious the first rebellion of Lucian against Viktor a few hours after being bitten by Lucian. It is through blood that Michael thus acquires knowledge of an important historical episode which is intended to ally him with the clan he now unwillingly belongs to. As Selene later specifies, "they are not hallucinations, they are memories, you've been bitten, his memories have passed down on you". Lucian's memories also provide the viewer with a coherent backstory that explains Viktor's prejudiced perspective and hatred: the spectator is further allied to the Lycans, whose narrative becomes a tale of ostracism, prejudice and withheld contact from the other races.

The link between blood and memories is rendered all the more fundamental if we consider that, as Selene affirms in the first instalment in the series, "digging into the past is forbidden". Indeed, she is forced to break into the library of the coven in order to access an ancient book containing the historical narration on Kraven's alleged extermination of the Lycans and his killing of Lucian. In the same respect, the official historian of the coven Andreas Tanis (Steven Mackintosh) has been exiled in a secret and isolated location because of his knowledge about Viktor's past and the confinement of William Corvinus. According to Viktor, Tanis used to spread "malicious lies", which were actually the truth about Viktor's political intrigues and his thirst for power.

The only way for a vampire to access the past other than listening to an elder's unquestionable version of the events is therefore by biting another vampire. This is what Markus does in Underworld Evolution when he visits Tanis and drinks his blood to learn the truth about the latter's dealings with Selene and Michael as much as to apprehend all the historical records contained in the books Tanis has written during the previous centuries. Markus drinks the historian's blood to possess a precise knowledge of both the past and present occurrences in order to enact his own plan and establish his future dominion.

Blood is therefore a symbol for communal and historical knowledge, for a precious heritage which needs to be preserved and remembered for the survival of the species. This occurs also in the case of Selene's awakening of Viktor in Underworld. Selene is in desperate need for help and advice and decides to awaken Viktor instead of Markus because she is (rightly) convinced that Kraven is secretly plotting against the vampire community. She therefore bites her wrist and offers her own blood to activate the mechanism which revitalizes (or, we could suggest, resuscitates) Viktor. It is through her blood that Viktor both awakens and simultaneously apprehends Selene's thoughts, memories and her version of the events almost representing the visual equivalent of a chaotic stream of consciousness. Specifically, through various close-ups the viewer can see the drops of blood entering Viktor's mouth and activating his body and heart beats. These images are alternated with Selene's thoughts and memories (even those representing her as a human child), thus 
suggesting that blood, memories and life are the very same thing.

Finally, blood is also explicitly presented as a vehicle for life for the single individual in these films. In $U n$ derworld Evolution, Selene offers her blood to Michael after he has been severely wounded by the policemen following him. He initially refuses her offer because he has not accepted his transformation into a monster yet. However, she insists that otherwise he would die; he then avidly drinks from her wrist, immediately regenerating his wounds and reaching a full recovery. Similarly, in Underworld: Awakening, Selene resuscitates one of the vampires of the coven she has discovered by literally touching his heart with her bleeding hand. Blood is thus pictured as a vehicle for recovery from serious injuries too.

This is epitomized by the fact that, in the second film, Selene finally acquires the power to defeat the invincible elder Markus through the blood of Alexander Corvinus (Derek Jacobi). Not only does Alexander's blood present her with an incredible strength and a resistance to physical injuries that would certainly kill other members of her species, but it also gives her one of the most precious gifts that a vampire could receive. As she discovers at the end of the film, in fact, her new hybrid nature of immortal human/vampire allows her to live under the light of the sun (the most lethal enemy of all vampires in this tetralogy as well as in many precedent films on such creatures), thus turning her into the strongest vampire in the history of her clan. Specifically, when offering Selene his blood before dying, Alexander urges her to hurry by saying: "Quickly now, before there is no more legacy left in my veins". Selene then asks: "What will I become?", to which he replies simply with the words: "the future". Blood is thus presented as containing the means to further a species' legacy and to adapt to, to progress into and improve oneself for the future. (See Figure 5.)

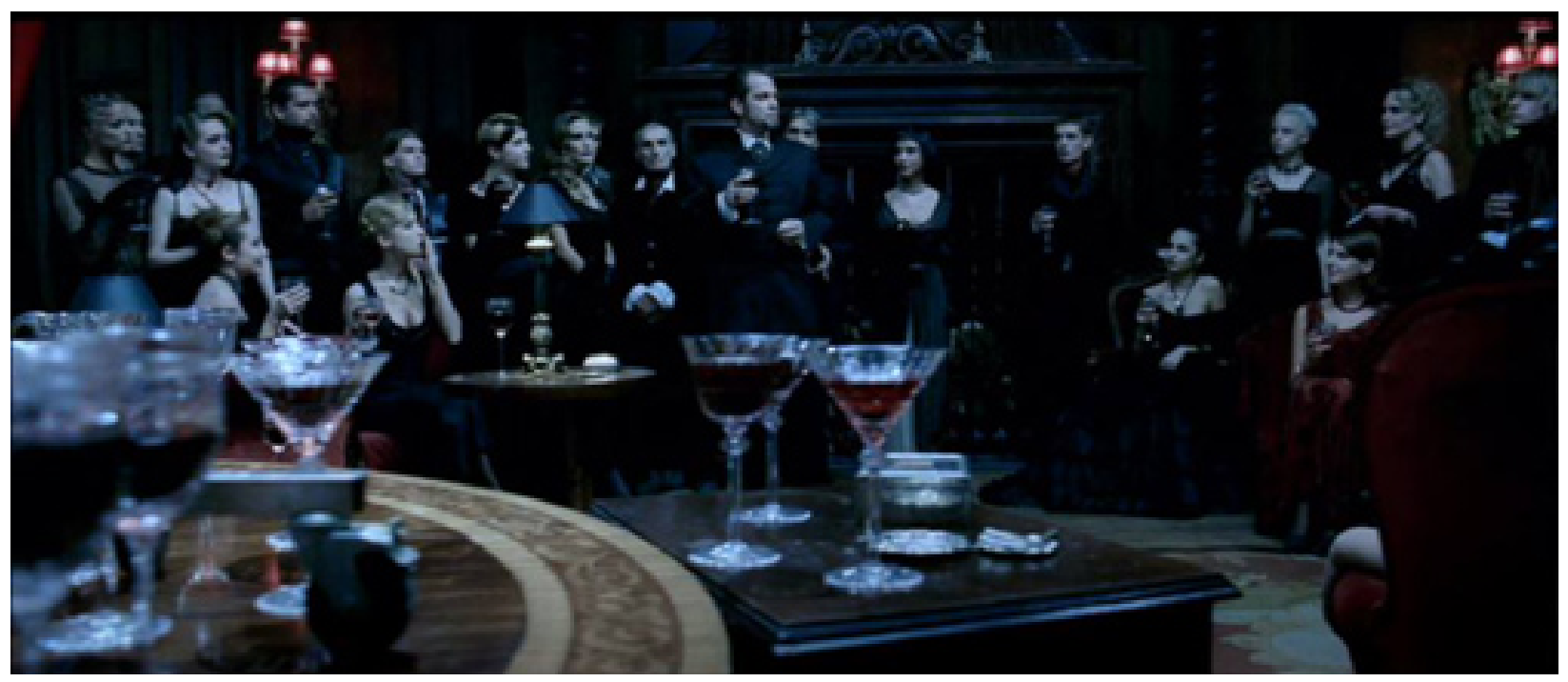

Figure 4: The coven of aristocratic vampires in Underworld (copyright Screen Gems)

It is important to note that, to further emphasize the nocturnal atmosphere of the narratives, a filter is used in almost every single scene of the four films to give everything a blue tinge which reproduces the moonlight. In this way, the images of blood lose the characteristic bright connotation of the red colour usually portrayed in previous films such as the entire Hammer series on vampires and werewolves. Indeed, in all of the productions focusing on the story of Dracula from Terence Fisher's milestone Horror of Dracula (1958) to Alan Gibson's The Satanic Rites of Dracula (1973), "brilliant color . . . sets strategic shots of blood against more sober background" (Leitch 102).

This is also the case of Dan Curtis's 1973 adaptation of Stoker's novel for the British television, in which red is the prevalent colour in the visuals of the film, from the main titles and the carriage at the beginning of the film to the wallpapers and furniture of the Western mansion. In the same respect, Fisher's The Curse of the Werewolf (1961) begins with several close-ups of the stains of red blood on the floor and the furniture, with the camera then following the traces of the murder up to the victim's body. Similarly, in Freddie Francis's Legend of the Werewolf (1975), a red filter is imposed on the images that reproduce the point of view of the 
monstrous creature before attacking its prey. During these scenes, the perspective of the werewolf closing upon its victims (and, specifically, on their throat) is given through a series of close-ups of the latter's terrorized faces alternating with those of the ferocious creature's face and its gnashing jaws dripping with blood. The red colour thus seems to have a less fundamental weight in the Underworld films than in previous horror productions on vampires and werewolves. Is this the way the directors of the tetralogy intend to offer a new representation of the colour red associated with blood and therefore of the very symbolism of blood?

The Underworld films offer a significant metamorphosis in the traditional representation of vampires and werewolves by not characterizing them as destructive presences preying on human beings. Indeed, the drinking of blood is not represented as an act motivated by hunger or by sexual desire. The kiss of the vampire and the bite of the werewolf almost become desirable: they are gifts to be cherished and preserved because they grant immortality and health. The prejudiced conception of blood as a transmitter of contagious diseases is held only by some of the vampires (mainly, Viktor). Such a prejudice is not given any objective confirmation in the end, but is continually set against a positive conception of blood as a vehicle for recovery, for truth on the historical past and on an individual's actions, and for the preservation of a species. The fear of illnesses is thus dispelled and finally exorcised.

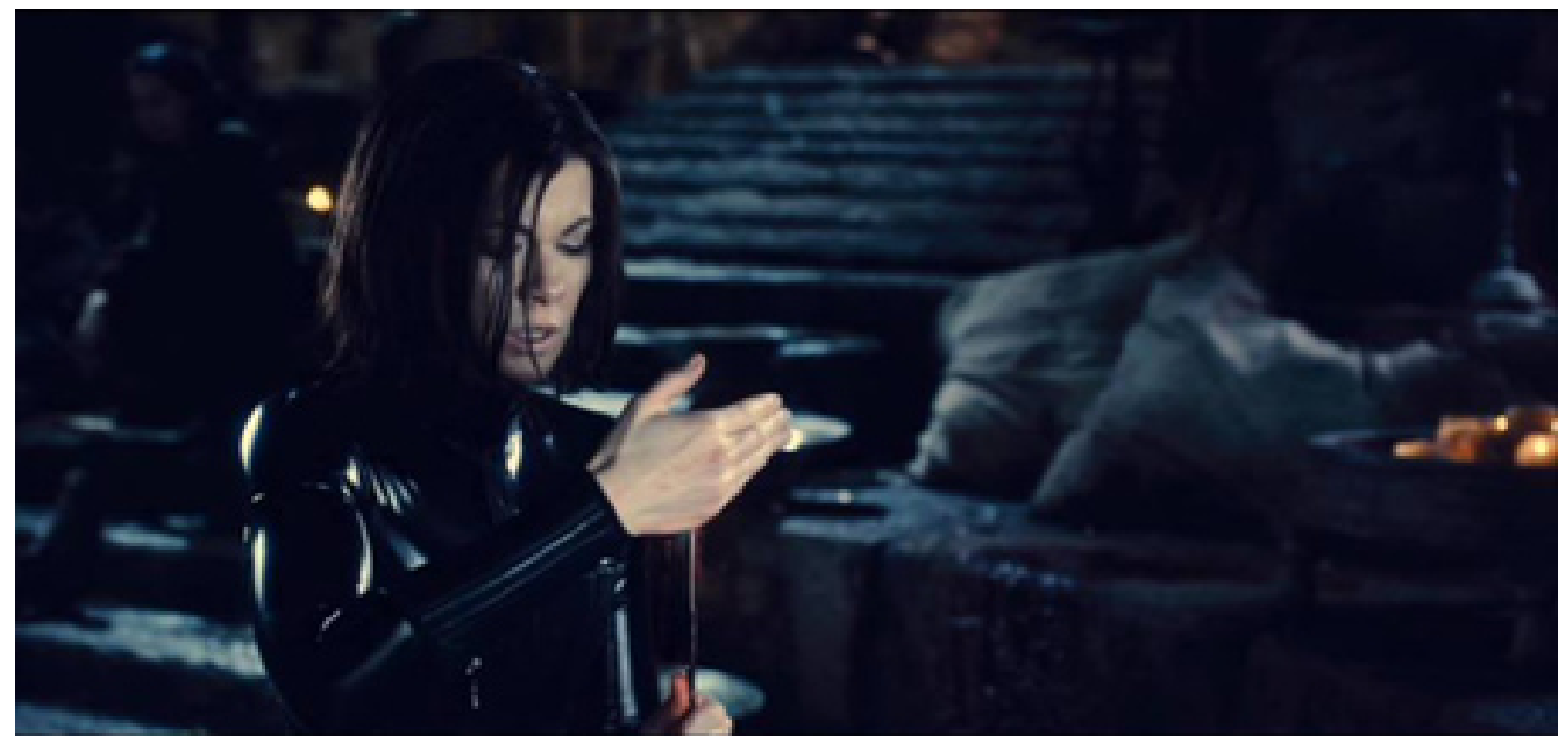

Figure 5: Selene (Kathe Beckinsale) cuts her own hand to revive another vampire by means of blood in Underworld (copyright Screen Gems)

\section{Notes}

\section{Notes}

1. It is interesting to note that during the year 1202 AD the Fourth Crusade began. This was initially intended to conquer and liberate Jerusalem, but was then diverted to the conquest of the Eastern Orthodox Constantinople in 1204, then capital of the Byzantine Empire, which brought about the creation of the Latin Empire. As in the case of the previous crusades, this was a war invested with sacredness (Flori: Le crociate 137), motivated by the papacy's condemnation of the Muslims and intended to free the territories from the pagans' tyranny (Flori: La guerra santa 326 ). Could we not associate this "sacred" military operation with the crusade initiated by Viktor in order to eliminate all the Lycans and obtain supremacy, a crusade actually motivated by his racial prejudices and that subsequently evolves into an open war after Lucian's rebellion at the end of the prequel film? 


\section{References}

\section{Bibliography}

Botting, Fred. The New Critical Idiom: Gothic. London: Routledge, 1996.

Flori, Jean. La guerra santa: La formazione dell'Idea di crociata nell'Occidente cristiano. Trans. Nicola Muschiello. Bologna, Mulino, 2003.

Le crociate Trans. Nicola Muschiello. Bologna: Mulino, 2003.

Freeland, Cynthia A. The Naked and the Undead: Evil and the Appeal of Horror. Boulder: Westview Press, 2000 .

Hendershot, Cindy. The Animal Within: Masculinity and the Gothic. Ann Arbor: University of Michigan Press, 2001.

Hopkins, Lisa. Screening the Gothic. Austin: University of Texas Press, 2005.

Leitch, Thomas. Adaptation 83 Its Discontents: From Gone with the Wind to The Passion of Christ. Baltimore: The Johns Hopkins University Press, 2009.

Naficy, Siamak Tundra. "The Werewolf in the Wardrobe." The Psychology of Harry Potter: An Unauthorized Examination of the Boy Who Lived. Ed. Neil Mulholland. Dallas: Benbella Books, 2006. 207-19.

Sanna, Antonio. "A Discourse Against Slavery: Underworld Rise of the Lycans." Interactions. 1:2 (Fall 2012). 133-36.

Smith, Andrew. Victorian Demons: Medicine, Masculinity and the Gothic at the Fin de Siècle. Manchester: Manchester University Press, 2004.

Spencer, Kathleen L. "Purity and Danger: Dracula, The Urban Gothic, and the Late Victorian Degeneracy Crisis." Gothic: Critical Concepts in Literary and Cultural Studies. Vol. 1. Ed. Fred Botting and Dale Townshend. London: Routledge, 2004. 304-30.

Spooner, Catherine. Contemporary Gothic. London: Reaktion Books, 2006.

Wells, Paul. The Horror Genre: From Beelzebub to Blair Witch. London: Wallflower, 2000.

\section{Filmography}

An American Werewolf in London. Dir. John Landis. Universal, 1981.

Bram Stoker's Dracula. Dir. Francis Ford Coppola. Columbia, 1992.

The Curse of the Werewolf. Dir. Terence Fisher. Universal, 1961.

Dracula. Dir. Tod Browning. Universal, 1931.

Dracula. Dir. Dan Curtis. Dan Curtis, 1973.

Dracula. Dir. John Badham. Universal, 1979.

Dracula A.D. 1972. Dir. Alan Gibson. Hammer, 1972.

Dracula Has Risen from the Grave. Dir. Freddie Francis. Hammer, 1968.

Dracula: Prince of Darkness. Dir. Terence Fisher. Hammer, 1965.

Ginger Snaps. Dir. John Fawcett. Motion International, 2000.

Ginger Snaps Back: The Beginning. Dir. Grant Harvey. Lions Gate Films, 2004.

Horror of Dracula. Dir. Terence Fisher. Hammer, 1958.

Interview with the Vampire. Dir. Neil Jordan. Geffen Pictures, 1994. 
Legend of the Werewolf. Dir. Freddie Francis. Tyburn Film, 1975.

Nosferatu. Dir. F.W. Murnau. Film Arts Guild, 1922.

The Satanic Rites of Dracula. Dir. Alan Gibson. Hammer, 1973.

Scars of Dracula. Dir. Roy Ward Baker. Hammer, 1970.

Taste the Blood of Dracula. Dir. Peter Sasdy. Hammer, 1969.

Underworld. Dir. Len Wiseman. Screen Gems, 2003.

Underworld Awakening. Dir. Mårlind \& Stein. Screen Gems, 2012.

Underworld Evolution. Dir. Len Wiseman. Screen Gems, 2006.

Underworld Rise of the Lycans Dir. Patrick Tatopoulos. Screen Gems, 2009.

The Werewolf. Dir. Fred F. Sears. Columbia, 1956.

Wolf. Dir. Mike Nichols. Columbia, 1994.

The Wolf Man. Dir. George Waggner. Universal, 1941.

The Wolfman. Dir. Joe Johnston. Universal, 2010.

\section{Author Information}

Antonio SANNA received his $\mathrm{PhD}$ at the University of Westminster in London. His publications include articles on James's "The Turn of the Screw", Stoker's Dracula, H. G. Wells's The Island of Dr. Moreau, Victorian ghost stories and Beowulf; the Alien quadrilogy, Ridley Scott's Hannibal and the Harry Potter films. He has contributed to The Dictionary of Literary Characters. 